\title{
Chayote Mosaic, a New Disease in Sechium edule Caused by a Tymovirus
}

\author{
M. Hord and W. Villalobos, Centro de Investigación en Biología Celular y Molecular (CIBCM), Universidad de \\ Costa Rica, Costa Rica; A. V. Macaya-Lizano, Escuela de Biología, Universidad de Costa Rica; and C. Rivera, \\ Centro de Investigación en Biología Celular y Molecular (CIBCM), Universidad de Costa Rica
}

\begin{abstract}
Hord, M., Villalobos, W., Macaya-Lizano, A. V., and Rivera, C. 1997. Chayote mosaic, a new disease in Sechium edule caused by a tymovirus. Plant Dis. 81:374-378.

A sap-transmissible virus was isolated from chayote (Sechium edule) in Costa Rica. Infected plants showed chlorotic spots and rings, and blotchy mosaics, which often coalesced to give a complete mosaic and leaf deformation. By electron microscopy, spherical virus-like particles of approximately $29 \mathrm{~nm}$ in diameter were visible, and cytological changes associated with the chloroplasts were observed. The virus particles sedimented in sucrose density gradients as two components, a top component of empty protein shells and a bottom component of electrondense particles. Electrophoretic analysis showed a single-stranded RNA of approximately $5.7 \mathrm{~kb}$ and capsid protein (CP) subunits of $\sim 22 \mathrm{kDa}$. The virus was identified as a member of the tymovirus group on the basis of particle morphology, size, sedimentation in sucrose gradients, cytopathological effects, and capsid protein and genome properties, and it was tentatively named chayote mosaic virus (ChMV).
\end{abstract}

Additional keywords: Cucurbitaceae, cytoplasmic inclusions, virus characterization

Sechium edule (Jacq.) Sw. (chayote) is a cucurbit native to Mesoamerica. It is grown mainly in the American continent from the south of the United States to Brazil and the Antilles, but also in the tropical and subtropical regions of Australia, New Zealand, South Europe, Asia, and Africa. Chayote has economic and nutritional significance in Central America, Brazil, and Mexico. In recent years, the cultivation of chayote in Costa Rica has quickly changed from a traditional backyard crop to a commercial monoculture oriented to the export market (3). Tomato spotted wilt virus is the only virus reported to infect this crop in America (21). A virus-like disease was observed in 1991 in commercial chayote fields in Costa Rica. The most frequently observed symptoms in chayote plants grown under field conditions were chlorotic spots and rings, and chlorotic blotchy mosaics, which often coalesced to give a complete mosaic and leaf deformation. The putative virus also caused size reduction and malformation of fruits. The objective of the present study was to identify the causal agent of the chayote mosaic disease. Preliminary results have been published (18).

\section{Corresponding author: C. Rivera}

E-mail: crivera@sol.racsa.co.cr

Accepted for publication 6 January 1997.

Publication no. D-1997-0128-05R

(C) 1997 The American Phytopathological Society

\section{MATERIALS AND METHODS}

Virus source. The virus was isolated from chayote that was infected naturally in the field. The virus was subsequently maintained in chayote plants in the greenhouse.

Mechanical transmission to chayote. Symptomatic chayote leaf tissue was ground in a mortar in cold $0.1 \mathrm{M}$ potassium phosphate buffer, pH 7.2. The plant sap was inoculated onto healthy chayote leaves dusted with Carborundum (600 mesh). Purified virus preparations obtained from sucrose density gradients were also inoculated onto healthy plants. The inoculated plants were maintained in the greenhouse and observed for symptom development.

Virus purification. Virus was purified from $100 \mathrm{~g}$ of infected chayote leaf tissue. The tissue was homogenized in $0.5 \mathrm{M}$ sodium citrate buffer, $\mathrm{pH} 6.5$, containing 5 mM EDTA and $0.5 \%$ thioglycolic acid, and filtered through two layers of cheesecloth. Extracts were clarified by emulsification with 5\% cold chloroform, followed by centrifugation at $4,000 \times g$ for $5 \mathrm{~min}$ in a Hitachi RPR-12 rotor (Hitachi Koki Co., Ltd., Tokyo, Japan). Polyethylene glycol (PEG) MW 6,000 and sodium chloride were added to the aqueous phase to a final concentration of $8 \%(\mathrm{wt} / \mathrm{vol})$ and $0.3 \mathrm{M}$, respectively. After the solution was stirred on ice for $1 \mathrm{~h}$, followed by $5 \mathrm{~h}$ at $4^{\circ} \mathrm{C}$, the precipitate was collected by centrifugation at $12,200 \times g$ for $5 \mathrm{~min}$ in a Hitachi RPR12 rotor, and the pellet was resuspended in one-half volume of $0.05 \mathrm{M}$ sodium citrate buffer, $\mathrm{pH}$ 7.0. The resulting suspension was subjected to two additional PEG precipitations. The final pellets were resus- pended in $15 \mathrm{ml}$ of $0.05 \mathrm{M}$ sodium citrate buffer, $\mathrm{pH} 7.0$, and then layered onto a 10 to $40 \%$ sucrose gradient in $0.05 \mathrm{M}$ sodium citrate buffer, $\mathrm{pH} 7$. After centrifugation at $60,000 \times g$ for $14 \mathrm{~h}$ in a Hitachi SW-25.1 rotor, two virus components were collected separately from the gradients based on their absorbance at 254 and $280 \mathrm{~nm}$. These were then subjected to dialysis against 0.05 M sodium citrate buffer, $\mathrm{pH} 7$.

Electron microscopy of viral particles. The purified virus components were negatively stained with $1 \%$ uranyl acetate on Formvar carbon-coated copper grids, examined in a Hitachi 7000 electron microscope, and photographed. One hundred particles from each component were measured, and the mean particle diameter was determined for each component.

Light microscopy of inclusion bodies. Epidermal strips from the lower leaf surfaces of healthy and infected plants, and pieces of leaf tissue with the surface abraded with sandpaper no. 600, were stained with Azure A and with Calcomine Orange-Luxol Brilliant Green BL (Aldrich Chemical Co., Inc., Milwaukee, WI) as described by Christie and Edwardson (2). The stained tissue was observed in a Zeiss Standard 19 light microscope.

Electron microscopy of inclusion bodies. Healthy and infected chayote leaf tissue pieces $(5 \times 5 \mathrm{~mm})$ were fixed in $2.5 \%$ glutaraldehyde and $2 \%$ formaldehyde in $0.05 \mathrm{M}$ sodium cacodylate- $\mathrm{HCl}, \mathrm{pH} 7.2$, (9) for $16 \mathrm{~h}$ at room temperature, postfixed with $1 \%$ osmium tetroxide, dehydrated in an ethanol series, and embedded in Spurr's epoxy resin. Sections were cut using an LKB 880 Ultratome III (Bromma, Sweden) and stained with uranyl acetate and lead citrate (17). Sections were examined in a Hitachi 7000 electron microscope and photographed.

Antiserum preparation and IgG purification. Antiserum was prepared by immunization of a New Zealand white rabbit with five intramuscular injections of a purified virus preparation (a mixture of the top and the bottom components obtained by sucrose gradient centrifugation). The initial injection contained $400 \mu \mathrm{g}$ of virus emulsified in Freund's complete adjuvant $(1: 1, \mathrm{vol} / \mathrm{vol})$. Each subsequent injection contained $200 \mu \mathrm{g}$ of virus emulsified in Freund's incomplete adjuvant. The sera were collected at weekly intervals, and the titer was determined by agar gel double diffusion (1) beginning 1 week after the third injection. When the titer reached 
$1: 256$, the rabbit was bled by cardiac puncture and the IgG was purified by protein A affinity chromatography (14).

Polyacrylamide gel electrophoresis of virion protein. Purified virus preparations (top and bottom components) and healthy and diseased plant extracts were disrupted in protein sample buffer $(60 \mathrm{mM}$ Tris- $\mathrm{HCl}$, $\mathrm{pH} 8.8,2 \%$ sodium dodecyl sulfate [SDS], 5\% 2-mercaptoethanol, $10 \%$ glycerol, and $0.01 \%$ bromophenol blue) and analyzed by $0.1 \%$ SDS-15\% polyacrylamide gel electrophoresis (SDS-PAGE) using a discontinuous buffer system (11). Protein bands were stained with Coomassie Brilliant Blue R-250. The molecular weight of the viral protein was determined by comparison with known molecular weight protein markers: trypsin inhibitor, 20K; $\alpha$-lactalbumin, $14.2 \mathrm{~K}$; bovine serum albumin, $66 \mathrm{~K}$; ovalbumin, $45 \mathrm{~K}$; glyceraldehyde-3$P$-dehydrogenase, $36 \mathrm{~K}$; bovine carbonic anhydrase, 29K; trypsinogen, $24 \mathrm{~K}$; and soybean (Sigma Chemical Co., St. Louis, MO).

Western blots. Proteins were separated by SDS-PAGE and transferred to nitrocellulose membranes (Bio-Rad Laboratories, Hercules, CA) as described by Towbin et al. (22). The membranes were developed according to Hammond and Jordan (5), using the anti-virus-IgG (dilution 1:2,000) as primary antibodies and goat anti-rabbit-IgG alkaline phosphatase conjugate (Sigma) as secondary antibodies. The blots were visualized with a substrate solution containing $14 \mathrm{mg}$ of nitroblue tetrazolium and $7 \mathrm{mg}$ of 5bromo-4-chloro-3-indolyl phosphate in 40 $\mathrm{ml}$ of $0.01 \mathrm{M}$ Tris, $0.1 \mathrm{M} \mathrm{NaCl}$, and 5 $\mathrm{mM} \mathrm{MgCl}$, $\mathrm{pH} 9.5$.
Viral nucleic acid extraction and analysis. Viral nucleic acid was extracted from purified virus preparations as described (M. J. Roossinck and P. S. White, unpublished).

The nature of the viral nucleic acid was determined by treatment with RNase A (Sigma) and DNase I (Sigma) after electrophoresis on $1 \%$ agarose gels in $1 \times \mathrm{TBE}$ (0.089 M Tris, $0.089 \mathrm{M}$ boric acid, $2 \mathrm{mM}$ EDTA) (20). Salmon sperm DNA (Sigma) and total RNA extracted from maize, kindly supplied by Kenneth Madriz (Thorvaldsensvej, Denmark) were included as controls. Gels were stained with ethidium bromide (20).

The molecular size of the viral genomic RNA was estimated in denaturing agarose gels. RNA molecular size markers (Promega Corporation, Madison, WI) and turnip yellow mosaic virus (TYMV) RNA kindly provided by Anne-Lise Haenni (Institut Jacques Monod, Paris) were included as standards. RNA was denatured by incubating for $15 \mathrm{~min}$ at $60^{\circ} \mathrm{C}$ prior to electrophoresis on a denaturing agarose gel (1\% agarose, $2.2 \mathrm{M}$ formaldehyde, $1 \times$ MOPS) in $1 \times$ MOPS running buffer (0.02 M 3-(N-morpholino) propanesulfonic acid, $\mathrm{pH} \mathrm{7,} \mathrm{containing} 0.08 \mathrm{M}$ sodium acetate and $0.01 \mathrm{M}$ EDTA, $\mathrm{pH}$ 8). Gels were stained with ethidium bromide (20).

\section{RESULTS}

Mechanical transmission. Healthy chayote plants mechanically inoculated with fresh sap from infected plants and with purified virus preparations showed systemic symptoms 2 weeks after inoculation. Symptoms in inoculated plants included chlorotic spots and rings, chlorotic blotchy mosaic, and leaf deformation. These symptoms were similar to those described and observed in field plants (Fig. $1 \mathrm{~A}$ to $\mathrm{C})$. Symptoms were not observed in noninoculated plants. The chayote plants did not produce fruit in the greenhouse; therefore, fruit symptoms could not be observed in mechanically inoculated plants.

Properties of virus particles. In sucrose density gradients, virus particles sedimented as two components visible as distinct light-scattering zones, coincident with peaks of UV absorbance at 280 and $254 \mathrm{~nm}$. Examination of negatively stained preparations showed that the top compo-

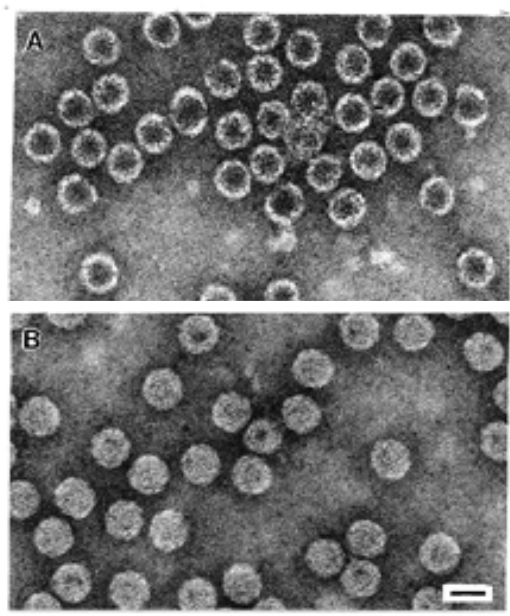

Fig. 2. Electron micrographs of negatively stained virus particles obtained from 10 to $40 \%$ sucrose density gradient. (A) Top component showing empty shells. (B) Bottom component showing electron-dense particles. Bar $=24 \mathrm{~nm}$.
A

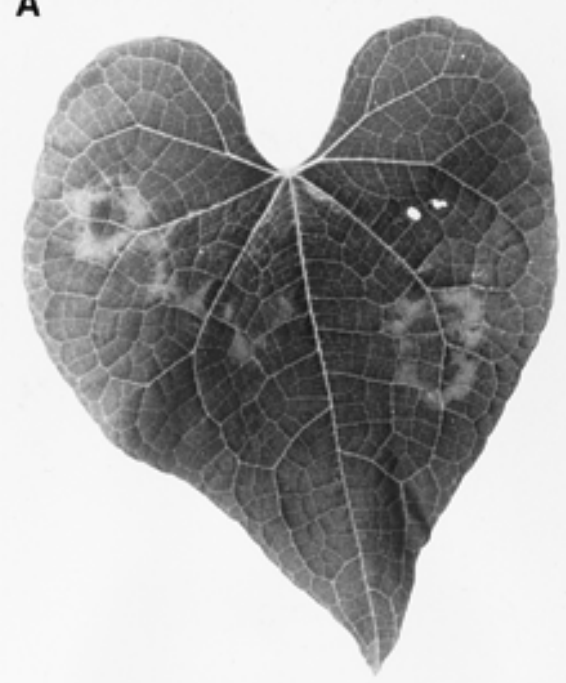

B

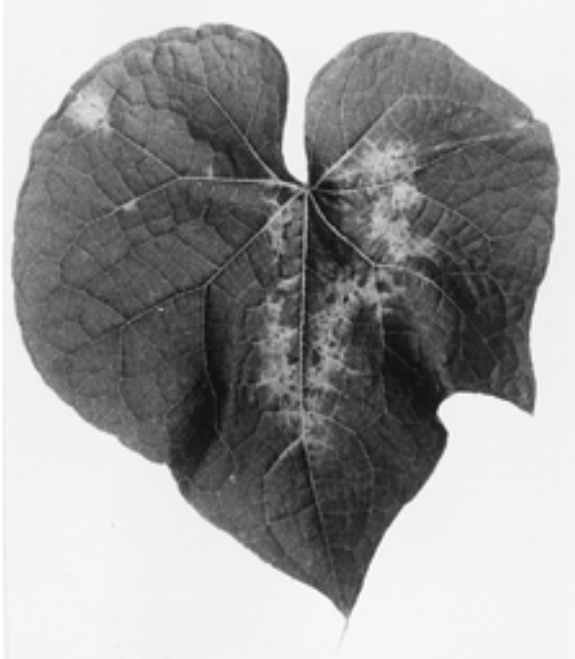

C

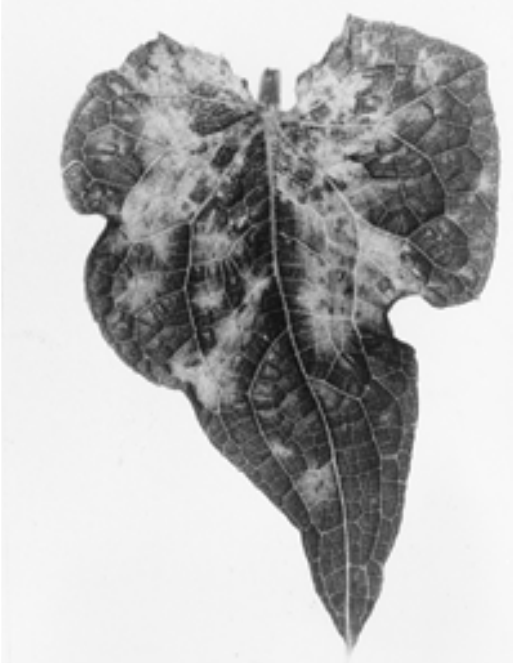

Fig. 1. Symptoms induced by chayote mosaic virus (ChMV) in the leaves of chayote plants naturally infected in the field. Leaf symptoms include (A) chlorotic spots and rings, (B) chlorotic blotchy mosaic, and (C) chlorotic mosaic and leaf deformation. 

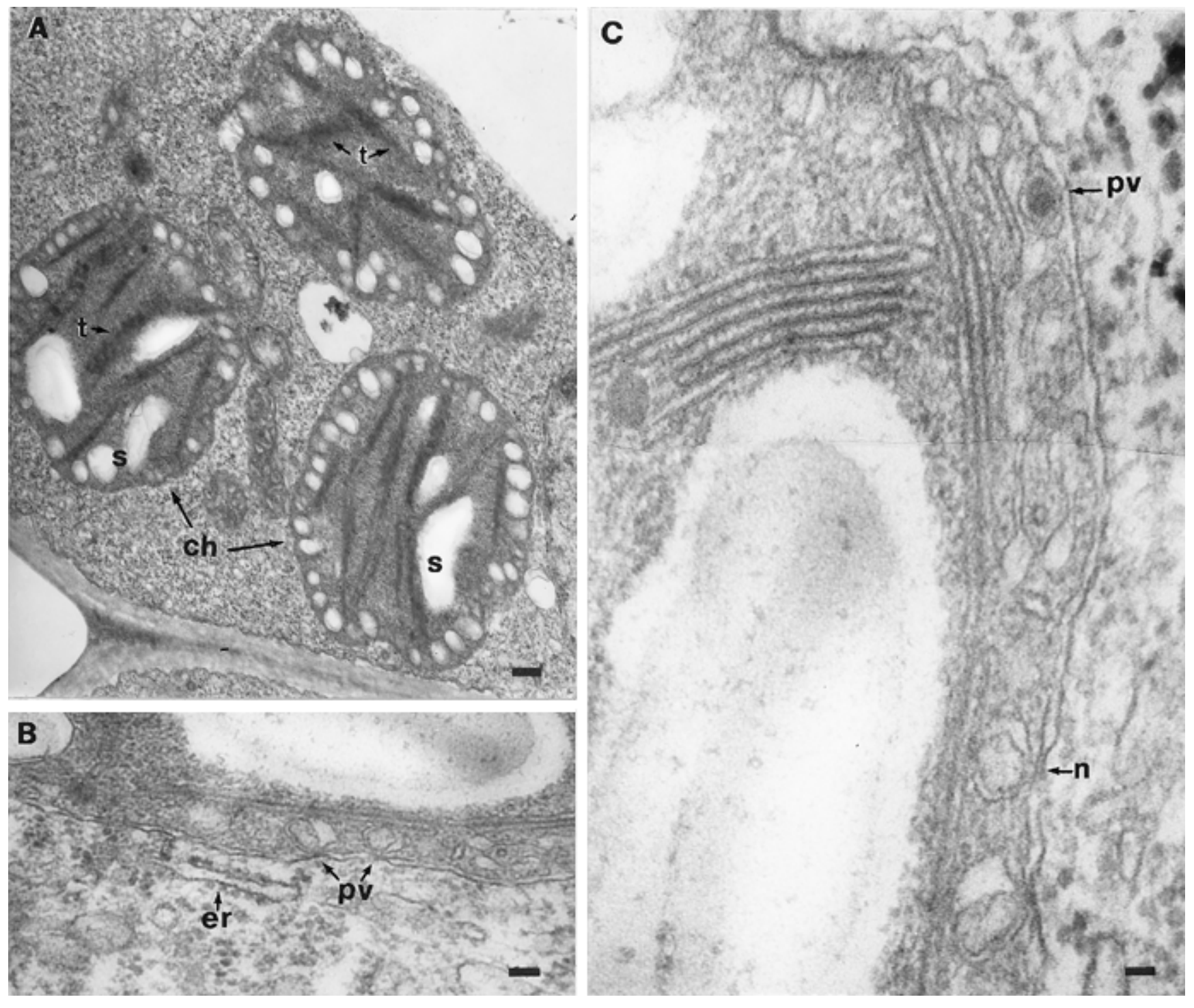

Fig. 3. Electron micrographs of thin sections of a chayote leaf cell infected with chayote mosaic virus (ChMV) and showing cytopathological symptoms. (A) Swollen, rounded, and grouped chloroplasts (ch) showing thylakoid disorganization (t), and starch aggregates $(\mathrm{s})$, bar $=215 \mathrm{~nm}$. (B) Peripheral vesicles (pv) of a chloroplast, with characteristic endoplasmic reticulum (er) in the neighboring cytoplasm, bar $=60.6 \mathrm{~nm}$. (C) Higher magnification (of B) of double membrane peripheral vesicles (pv) containing densely stained fibrillar material, their necks (n) opening into the cytoplasm, bar $=34.45 \mathrm{~nm}$.

nent consisted mostly of empty protein shells (Fig. 2A), whereas the bottom component contained mostly electron-dense nucleoprotein particles (Fig. 2B). Both types of particles presented an icosahedral symmetry and were approximately $29 \mathrm{~nm}$ in diameter.

Inclusion bodies and cytological changes. Stained masses surrounding plastids were observed by light microscopy in mesophyll cells of virus-infected chayote plants, but not in healthy controls. These inclusions stained reddish in Azure A. Angular crystalline cytoplasmic inclusions stained with Azure A were observed in guard cells of infected leaves, trichomes, and epidermal cells (not shown).

Cytological changes associated with the chloroplasts of infected leaf tissue were observed by electron microscopy. Chloroplasts were swollen and rounded, with irregular outlines. The thylakoids were disorganized, with large starch aggregates inside vacuoles (Fig. 3A). Small peripheral vesicles with double membrane structures appeared on the chloroplast surface, some of them containing densely stained fibrillar material (Fig. 3B and C). In some vesicles, necks opening into the cytoplasm were visible, and endoplasmic reticulum membranes appeared close to the chloroplast vesicles (Fig. 3B and C).

Gel electrophoresis of viral protein and Western blot analysis. A single protein species of approximately $22 \mathrm{~K}$ was detected by SDS-PAGE in purified virus preparations of top and bottom components (Fig. 4, lanes 3 and 4). The same $22 \mathrm{~K}$ protein was observed in crude sap from symptomatic plants (Fig. 4, lane 2). No comparable band was present in crude sap of healthy plants (Fig. 4, lane 5). In Western blot analyses of the samples, anti-virus antibodies (1:2,000 dilution) reacted specifically with the $22 \mathrm{~K}$ protein of the top and the bottom virus components (Fig. 4, lanes 6 and 7), but did not react with normal plant proteins (data not shown).

Viral nucleic acid extraction and analysis. The viral nucleic acid was susceptible to digestion by RNase but not DNase (not shown). A single RNA with an estimated molecular size of $\sim 5.7 \mathrm{~kb}$ was detected in RNA extracted from the bottom component in denaturing agarose gels (Fig. 5, lane 2). Migration of the RNA was similar to that of TYMV RNA (Fig. 5, lane 3) under denaturing conditions.

\section{DISCUSSION}

An isometric virus particle of approximately $29 \mathrm{~nm}$ in diameter was identified as the causal agent of the chayote mosaic disease observed in commercial fields in Costa Rica. The disease was reproduced by inoculating healthy plants with plant sap and purified virus preparations, confirming the pathogenicity of the virus according to Koch's postulates (19). The virus isolate 


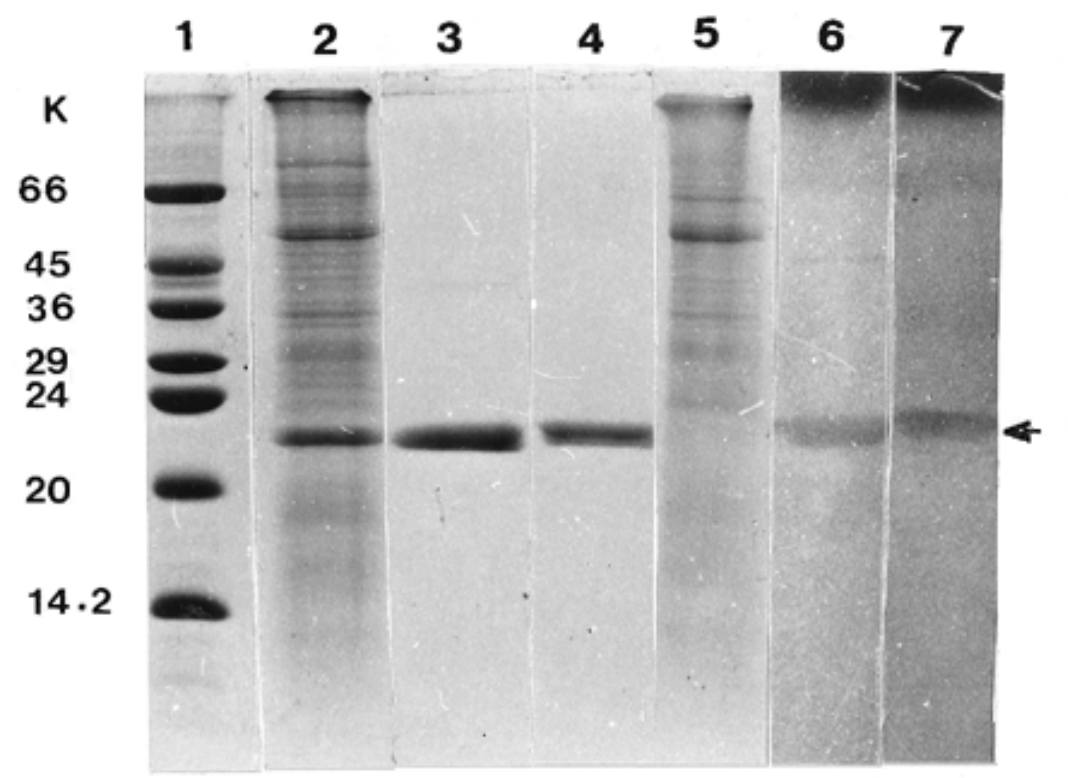

Fig. 4. Electrophoretic and immunological analysis of chayote mosaic virus (ChMV) coat protein from purified virus preparations and infected plant sap. Lanes 1 to 5, sodium dodecyl sulfate-polyacrylamide gel electrophoresis (SDS-PAGE) stained with Coomassie Brilliant Blue R-250. Protein molecular weight standards (Sigma) (lane 1), crude sap from a diseased plant (lane 2), ChMV top component (lane 3), ChMV bottom component (lane 4), and crude sap from a healthy plant (lane 5). Position and size of protein markers are indicated to the left. The position of the CP is indicated to the right. Western blot analysis using anti-ChMV antibodies was conducted on purified top (lane 6) and bottom (lane 7) components.

from chayote, tentatively named chayote mosaic virus (ChMV), has many properties in common with the members of the tymovirus group of plant viruses. ChMV was mechanically transmitted from chayote to chayote. Back-inoculation of purified virus to the original host plant has been achieved with all tymoviruses except poinsettia mosaic virus (PoiMV) (13). The icosahedral symmetry, the size of $29 \mathrm{~nm}$ for the virus particles, and the particle sedimentation pattern of ChMV as two major components in sucrose gradients are characteristics similar to those reported for other members of the tymovirus group $(7,10,15)$. The reddish-staining masses observed by light microscopy surrounding the plastids in mesophyll cells of ChMV-infected chayote plants were similar to those reported by Christie and Edwardson (2) for other tymoviruses. The cytopathological effects observed by electron microscopy in the chloroplasts of ChMV-infected plants are also similar to those reported for other members of the tymovirus group $(4,6)$ and are considered to be one of the main characteristics of tymoviruses (12).

When disrupted ChMV was analyzed by SDS-PAGE, a single major protein of $22 \mathrm{~K}$ was consistently found in both the bottom and the top components of ChMV. A protein migrating in the same position was detected by Western blot using anti-ChMV antibodies. The $22 \mathrm{~K}$ protein thus corresponds to the ChMV CP. It is slightly larger than the $20 \mathrm{~K}$ reported for other tymoviruses (7). The viral genome of ChMV is a single-stranded RNA whose size was estimated to be $5.7 \mathrm{~kb}$. The ChMV RNA is similar in size to the TYMV genomic RNA, and also to the genomic RNAs of the other members of the tymovirus group (8).

This is the first report of the natural occurrence of a tymovirus in a cucurbit host in Mesoamerica. Preliminary data (not published) indicate that ChMV has a very narrow host range, limited to a few members of the Cucurbitaceae. The host range of the tymoviruses is usually very narrow, limited either to one family or to a few hosts of not more than six families $(7,10)$. Only one other tymovirus, wild cucumber mosaic virus (WCMV), which was isolated from naturally infected wild cucurbits in North America, has been reported to be largely restricted to the Cucurbitaceae $(7,16,23)$. We are comparing ChMV with other members of the tymovirus group by host range, serology, and sequence homology to determine if the ChMV is a strain of a known tymovirus or a new member of this group of plant viruses.

\section{ACKNOWLEDGMENTS}

This work was supported by funds from La Red Latinoamericana de Botánica, by the Commission of the European Communities, and by the Program for Characterization and Diagnosis of Plant Viruses and Viroids of the Centro de Investigación en Biología Celular y Molecular (PCDV-CIBCM) de la Universidad de Costa Rica. We thank Reynaldo Pereira for his assistance with the photography.

\section{LITERATURE CITED}

1. Ball, E. M. 1990. Agar Double Diffusion, Plates (Ouchterlony): Viruses. Pages 111-120 in: Serological Methods for Detection and

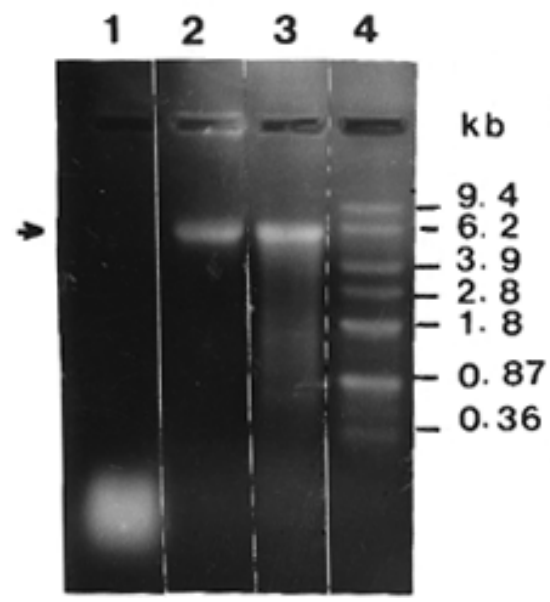

Fig. 5. Analysis of chayote mosaic virus (ChMV) RNA by denaturing agarose gel electrophoresis. ChMV RNA, top component (lane 1), ChMV RNA, bottom component (lane 2), turnip yellow mosaic virus (TYMV) RNA (lane 3), and RNA size markers (Promega) (lane 4). Sizes and positions of the RNA markers are indicated to the right. The positions of the TYMV and ChMV genomic RNAs are indicated by arrow to the left.

Identification of Viral and Bacterial Plant Pathogens. R. Hampton, E. Ball, and S. De Boer, eds. American Phytopathological Society, St. Paul, MN.

2. Christie, R. G., and Edwardson, J. R. 1977. Light and electron microscopy of plant virus inclusions. Fla. Agric. Exp. Stn. Monogr. Serv. 9.

3. Flores, E. 1989. El chayote, Sechium edule, Swartz (Cucurbitaceae). Rev. Biol. Trop. 37:1-54.

4. Francki, R. I. B., Milne, R. G., and Hatta, T. 1985. Tymovirus Group. Pages 117-136 in: Atlas of Plant Viruses. Vol. I. R. I. B. Francki, R. G. Milne, and T. Hatta, eds. CRC Press, Boca Raton, FL.

5. Hammond, J., and Jordan, R. L. 1990. Dot Blot (Viruses) and Colony Screening. Pages 237-246 in: Serological Methods for Detection and Identification of Viral and Bacterial Plant Pathogens. R. Hampton, E. Ball, and S. De Boer, eds. American Phytopathological Society, St. Paul, MN.

6. Hatta, T., and Matthews, R. E. F. 1974. The sequence of early changes in Chinese cabbage leaf cells following systemic infection with turnip yellow mosaic virus. Virology 59:383386.

7. Hirth, L., and Givord, L. 1988. Tymoviruses. Pages 163-212 in: The Plant Viruses, Polyhedral Virions with Monopartite RNA Genomes. Vol. III. R. Koenig, ed. Plenum Press, New York.

8. Kadaré, G., Drugeon, G., Savithri, H. S., and Haenni, A.-L. 1992. Comparison of the strategies of expression of five tymovirus RNAs by in vitro translation studies. J. Gen. Virol. 73:493-498.

9. Karnowsky, M. J. 1965. A formaldehydeglutaraldehyde fixative of high osmolality for use in electron microscopy. J. Cell. Biol. 27:137.

10. Koenig, R., and Lesemann, D. E. 1979. Tymovirus group. No 214. C.M.I./A.A.B. Descriptions of Plant Viruses. Commonw. Mycol. Inst./Assoc. Appl. Biol., Kew, England.

11. Laemmli, U. K. 1970. Cleavage of structural proteins during the assembly of the head of bacteriophage T4. Nature 227:680-685.

12. Lesemann, D. E. 1977. Virus-group specific 
and virus specific cytological alterations induced by members of the Tymovirus group. Phytopathol. Z. 90:315-336.

13. Lesemann, D. E., Koenig, R., Huth, W., Brunt, A. A., Phillips, S., and Barton, R. J. 1983. Poinsettia mosaic virus-a tymovirus? Phytopathol. Z. 107:250.

14. Lindmark, R., Thoren-Tolling, K., and Sjoquist, J. 1983. Binding of immunoglobulins to Protein A and immunoglobulin levels in mammalian sera. J. Immunol. Methods 62:113.

15. Matthews, R. E. F. 1970. Turnip yellow mosaic virus. No 2. C.M.I./A.A.B. Descriptions of Plant Viruses. Commonw. Mycol. Inst./Assoc. Appl. Biol., Kew, England.

16. Milne, K. S., Grogan, R. G., and Kimble, K.
A. 1969. Identification of viruses infecting cucurbits in California. Phytopathology 59:919-928.

17. Reynolds, E. S. 1963. The use of lead citrate at high $\mathrm{pH}$ as an electron-opaque stain in electron microscopy. J. Cell Biol. 17:208-212.

18. Rivera, C., Villalobos, W., and Macaya-Lizano, A. V. 1995. Virus del mosaico del chayote, un posible nuevo miembro del grupo Tymovirus: Sintomatología, citopatología y algunas propiedades de las partículas. Page 28 in: Proc. XXXVIII Annu. Meet., Soc. Biol. Viña del Mar, Chile.

19. Rivers, T. M. 1937. Viruses and Koch's postulates. J. Bacteriol. 33:1-12.

20. Sambrook, J., Fritsch, E. F., and Maniatis, T. A. 1989. Molecular Cloning: A Laboratory
Manual. 2nd ed. Cold Spring Harbor Laboratory, Cold Spring Harbor, NY

21. Silveira, W. G., Jr., Avila, A. C., and Muñoz, J. O. 1985. Chuchu (Sechium edule Sw.): Nova especie hospedeira do virus de viracabeca do tomateiro. Fitopatol. Brasil. 10:661-665.

22. Towbin, H., Staehelin, T., and Gordon, J. 1979. Electrophoretic transfer of proteins from polyacrylamide gels to nitrocellulose sheets: Procedure and some applications. Proc. Natl. Acad. Sci. USA. 76:4350-4354.

23. van Regenmortel, M. H. V. 1972. Wild cucumber mosaic virus. No. 105. C.M.I./A.A.B. Descriptions of Plant Viruses. Commonw. Mycol. Inst./Assoc. Appl. Biol., Kew, England. 